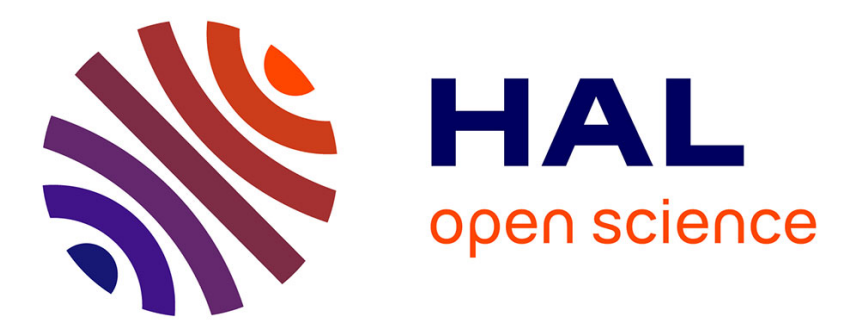

\title{
Remittances and bond yield spreads in emerging market economies
}

\author{
Hippolyte Wenéyam Balima, Jean-Louis Combes
}

\section{To cite this version:}

Hippolyte Wenéyam Balima, Jean-Louis Combes. Remittances and bond yield spreads in emerging market economies. Review of International Economics, 2019, 27 (1), pp.448-467. hal-01990352

\section{HAL Id: hal-01990352 \\ https://hal.science/hal-01990352}

Submitted on 7 Dec 2021

HAL is a multi-disciplinary open access archive for the deposit and dissemination of scientific research documents, whether they are published or not. The documents may come from teaching and research institutions in France or abroad, or from public or private research centers.
L'archive ouverte pluridisciplinaire HAL, est destinée au dépôt et à la diffusion de documents scientifiques de niveau recherche, publiés ou non, émanant des établissements d'enseignement et de recherche français ou étrangers, des laboratoires publics ou privés. 


\title{
Remittances and Bond Yield Spreads in Emerging Market Economies ${ }^{1}$
}

\author{
Hippolyte Wenéyam BALIMA ${ }^{\left(\text {a) }{ }^{*}\right)}$ and Jean-Louis COMBES ${ }^{(b)}$
}

(a) International Monetary Fund, 700, $19^{\text {th }}$ Street, Washington, D.C., USA.

(b) School of Economics and CERDI, University of Clermont Auvergne, 26 avenue Léon Blum, 63000 Clermont-Ferrand, France.

${ }^{(*)}$ Corresponding Author: hbalima@imf.org

\begin{abstract}
This paper tests whether remittances reduce bond yield spreads in emerging market economies. Drawing upon instrumental variable techniques, our paper reveals that remittance inflows significantly reduce bond yield spreads. This result is robust to different specifications, alternative instrumentation techniques, additional control variables, and the use of Credit Default Swap (CDS) spreads in place of bond spreads. In addition, we find that the effect of remittances on spreads (i) is larger in (more) poorly developed financial systems, (ii) increases with the degree of trade openness, (iii) is larger in low fiscal space regimes, and (iv) is larger in non-remittance dependent countries. The paper concludes that policies that improve the measurement of remittance inflows and reduce their transfer costs or that enable countries to develop securitization of remittances and diaspora bonds could help emerging market economies to leverage remittances for international capital market access.
\end{abstract}

Keywords: Government bond yield spreads; Fiscal policy; Remittances; Emerging markets.

JEL codes: E44, E62, F24, F35, G15.

\footnotetext{
1 We benefited from extensive comments from the Associate Editor (Sylvia Kaufmann) and from two anonymous Referees. We are also grateful to Marcelo Olarreaga, Sandra Poncet, Camelia Turcu, and participants of the 25th Research in International Economics and Finance (RIEF) Annual Conference in Orleans for their insightful comments and suggestions. The usual disclaimers apply.
} 
The relatively stable nature of remittances suggests that countries with access to significant remittance inflows may be less prone to damaging fluctuations [...]. In extreme cases, remittances might reduce the probability of financial crises.

— International Monetary Fund, World Economic Outlook (April 2005, Chapter II, p.73)

\section{Introduction}

Access to international capital markets has dramatically deteriorated for many countries, particularly for emerging countries, in the wake of the 2008-2009 financial crisis. According to Arellano (2008), emerging market countries generally tend to bear highly countercyclical borrowing costs due to the cyclical changes in the access to international credit. The countercyclical nature of interest rates means that borrowing costs increase in times of recession and decrease in times of expansion. This poses significant challenges for policymakers, leading many academic researchers to investigate the determinants of sovereign bond yield spreads.

There is a large body of literature on the determinants of government bond yield spreads. Bond spreads are generally associated with two main drivers: (i) domestic macroeconomic fundamentals [Edwards (1984), Baldacci and Kumar (2010), Hilscher and Nosbusch (2010), Arezki and Brückner (2011), Baldacci et al. (2011), Hatchondo et al. (2012), Comelli (2012), Aizenman et al. (2013), Eichler (2014), Costantini et al. (2014)], and (ii) global conditions on financial markets and international factors [Arora and Cerisola (2001), Sy (2002), Bellas et al. (2010), Jaramillo and Tejada (2011), Arslanalp and Poghosyan (2014)]. The factors considered as important determinants of spreads include GDP growth, fiscal space, public debt, foreign exchange reserves, inflation, crisis episodes, the VIX index and the FED policy rate.

Despite the amount of literature on the determinants of bond spreads, with the notable exception of Ratha (2007), little attention has been given to the potential impact of countercyclical capital inflows, namely remittances. In a survey, this author defines a standard country creditworthiness model and shows that in Lebanon and Haiti including remittances in the debt-to-export ratio can result in a spread reduction of 130 to 334 basis points. Apart from this stylized fact, to the best of our knowledge, no empirical study has examined the effect of remittances on bond spreads. This is somewhat surprising since the empirical literature on capital flows suggests that some forms of capital are more countercyclical than others. More specifically, it has been pointed out that remittances inflows may be countercyclical, increasing for the recipient country during crisis and times of economic hardship. For 
instance, Figure 1 plots the evolution of remittances both as a percentage of GDP and in billions of US dollar on the left-hand side, and remittances-to-GDP and real GDP growth on the right-hand side, for our sample of emerging market economies. A picture emerges that the amount of remittances has been increasing over time, reaching 230 billion of US dollar in 2012 (see the left-hand side of the figure). In addition, the ratio of remittances-to-GDP has increased during some valleys of the business cycle (see the right-hand side of the figure). Given the countercyclical nature of the borrowing costs borne by emerging market countries, this begs the following question: are remittances reliable stabilizers on government bond markets? In this paper, we contribute to the literature on the determinants of government bond yield spreads by analyzing the effects of remittances on bond spreads in emerging market economies.

Figure 1. Evolution of remittances and real GDP growth.
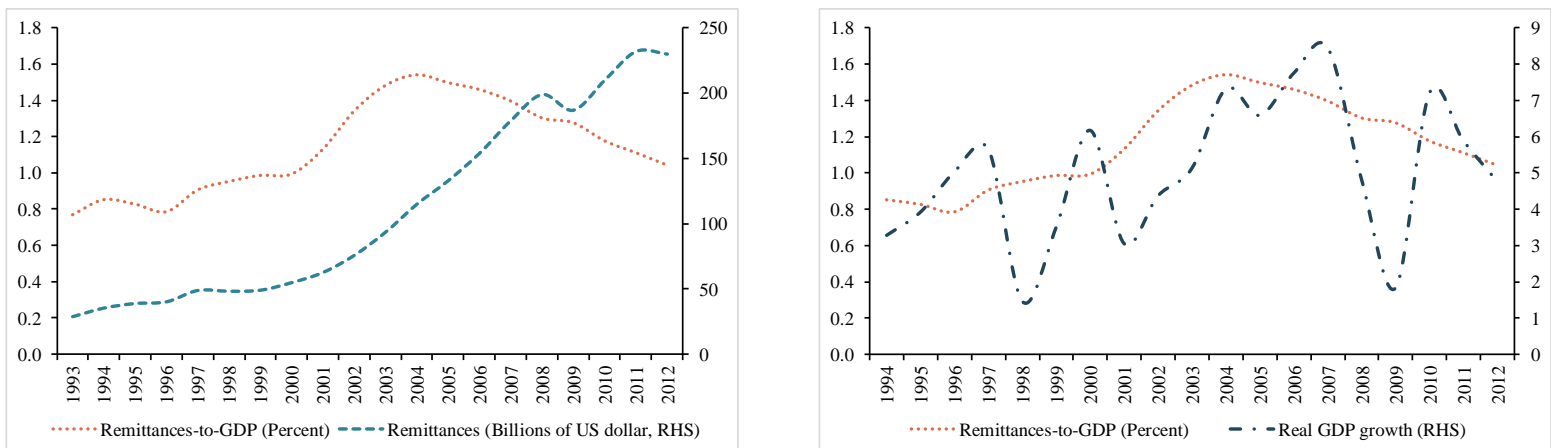

Source: Authors' computation using Word Development Indicators.

There are a number of mechanisms through which remittances can affect the borrowing costs faced by emerging market countries. First, remittances serve to increase the receiving country's fiscal space. Indeed, by enabling households to increase consumption and investment, remittances can raise the receiving country's revenue base and so reduce the marginal cost of raising revenues (Chami et al., 2008). In that vein, remittances improve the receiving country's creditworthiness in the international capital market. Second, previous studies highlight the countercyclical behavior of remittances with respect to economic conditions in migrants' countries of origin (Frankel, 2011; Mandelman, 2013; Shapiro and Mandelman, 2016). Consequently, remittances can function as an insurance mechanism by absorbing negative shocks, particularly those affecting the receiving country's bond markets. Third, remittances can have an impact on bond spreads through the securitization of future remittance flows, helping the borrowing country to mitigate its currency convertibility risk 
and build a credit history. ${ }^{2}$ The fourth mechanism is the diaspora bonds channel. Originally used by Japan and China in the early 1930s and then by Israel (since 1951) and India (since its balance of payment crisis in 1991), a diaspora bond can serve as a cheap and stable source of financing, especially during bad economic times. Indeed, unlike other foreign investors, who are typically concerned about a borrowing country's creditworthiness, members of a country's diaspora can accept lower interest rates on their home country's government bonds as an act of "patriotism" or in solidarity and support of family and compatriots or solely for the satisfaction of contributing to the development of their country of origin. ${ }^{3}$ Consequently, diaspora bonds can increase bond market liquidity and reduce bond spreads. We should, therefore, expect a reduction in sovereign bond spreads with remittance inflows.

To investigate the role of remittances on bond spreads, we rely on annual data of 38 emerging market countries over the period 1993 to 2012. We tackle the potential endogeneity issues of remittances by using an instrumental variable (IV) strategy. We use the potential earning in migrants' host countries, proxied by real GDP per capita of destination country weighted by the share of emigrants in the host country, as an external instrument for remittances. The underlying idea is that remittances sent home are positively related to the economic conditions in migrants' countries of residence. Consequently, the potential earning in migrants' host countries might be a good instrument for remittances after controlling for international business cycle transmission through the variables of trade openness, capital account openness and financial crises. Our results are as follows. First, remittances significantly reduce bond spreads in emerging markets. The magnitude of this favorable effect is economically meaningful, namely, a spread savings of 3 basis points following an increase of 1 percentage point of remittances-to-GDP ratio. This result withstands several robustness checks, including alternative specifications, alternative instrumentation techniques, additional control variables and the use of Credit Default Swap (CDS) spreads rather than bond spreads. Second, we examine the potential heterogeneity of the effect of remittances. We provide evidence that the effect of remittances on spreads (i) is larger in less developed financial systems, (ii) increases with the degree of a country's trade openness, (iii) is larger in low fiscal space regimes, and (iv) is larger in non-remittance dependent countries.

\footnotetext{
${ }^{2}$ Even if remittance securitization is quite recent, it has allowed many countries to raise cheaper and longer-term funds in the financial market. For instance, Ratha (2007) suggests that remittance securitization allowed Brazil to raise 4 billion USD during the election period in 2002, with a spread saving of over 700 basis points. In the case of African countries, Ghana and Nigeria also raised 40 and 50 million USD, respectively, in the bond markets by using flows of remittances (Shimeles, 2010).

${ }^{3}$ For instance, in 2011, the Greek government used this funding mechanism when its borrowing conditions in the financial market became very costly.
} 
The rest of the paper is organized as follows. Section II presents the data, the empirical model and the identification strategy. Section III discusses the baseline results and the different robustness tests. Section IV addresses the potential heterogeneity of the effect of remittances on bond spreads. The conclusion and a discussion are offered in Section V.

\section{Data, Empirical Model, and Identification Strategy}

\subsection{Data and Empirical Model}

Based on the availability of data on government bond yield spreads, our sample consists of annual unbalanced panel data on 38 emerging markets for the period 1993-2012. We measure government borrowing costs using JP Morgan's Emerging Market Bond Index Global (EMBIG). The EMBIG measures the yield spread between each emerging market country and the United States (US), assuming that US sovereign bonds are risk-free. EMBIG tracks total return for traded external debt instruments and includes Brady bonds, loans, and Eurobonds with a minimum size of $\$ 500$ million and an average maturity of 12 years.

Our main variable of interest is remittances inflows. ${ }^{4}$ The literature usually distinguishes three different items reported in the statistic of the balance of payment: workers' remittances, compensation of employees, and migrants' transfers. Workers' remittances refer to current transfers by employed migrants who do not reside in their countries of origin. Compensation of employees includes income of border, seasonal, and other short-term workers who work away from their usual residence, as well as earnings provided to residents by non-resident entities. Migrants' transfers represent contra-entries, flows of goods and changes in financial items resulting from inter-country migration of individuals. A common approach in the empirical literature has been to combine these three components (see Giuliano and Ruiz-Arranz, 2009; Aggarwal et al., 2011). However, as discussed in Chami et al. (2008), the measurement of remittances matters when assessing their macroeconomic implications, as workers' remittances most closely corresponds to the item that researchers and policymakers have in mind when discussing remittance flows: periodic, unrequited, and nonmarket transfers between residents of different countries. As such, researchers and policymakers argue that the inclusion of compensation of employees and migrants' transfers can "pollute" the database with "non-remittance" behavioral characteristics and thus recommend the use of workers' remittances alone [see Chami et al. (2008) for a discussion]. Following this recommendation,

\footnotetext{
${ }^{4}$ An early version of this paper compares the effect of remittances and aid on spreads and finds the effect of aid not statistically different from zero.
} 
we use workers' remittances as our main independent variable in the baseline analysis. In a robustness check, we also add up the three items previously discussed. Data on workers' remittances comes from the World Bank's development indicator.

The empirical model is:

$$
\text { Spread }_{i t}=\alpha+\beta_{1} R_{i t}+\sum_{k} \lambda_{k} X_{k, i t}+\eta_{i}+\varepsilon_{i t}
$$

where Spread $_{i t}$ is the sovereign bond yield spread for country $i$ in year $t, R_{i t}$ is the amount of worker's remittances received (in \% of GDP), $X_{k, i t}$ is a vector of $k$ control variables, and $\alpha, \eta_{i}$ and $\varepsilon_{i t}$ are the constant, country-fixed-effects, and the error term, respectively. To facilitate the interpretation, the variables Spread $_{i t}$ and $R_{i t}$ are expressed in logs.

The matrix of control variables contains the following 11 items. Real GDP growth is expected to improve public debt sustainability in terms of market access, due to potential higher public revenues, thus decreasing yield spread. Total government debt (\% of GDP) should increase yield spread, as higher public debt raises concerns about the government's ability to service its debt. Government's fiscal deficit (\% of GDP) is expected to increase bond spread. Indeed, a large fiscal deficit may reduce national saving and raise aggregate demand (Elmendorf and Mankiw, 1999), thus translating into an excess supply of government bonds and increasing bond spread. Total external reserves should reduce bond spreads, since higher reserves strengthen government's ability to repay debt. The institutional quality index is also expected to reduce bond spread, as sound institutions should enhance the sustainability of public finances. ${ }^{5}$ The current account balance (\% of GDP; we exclude remittances) is expected to decrease risk premium, since a higher current account surplus improves a government's ability to repay its external debt. The real effective exchange rate (REER) can affect a country's borrowing costs through trade performance and domestic and external balance sheets. On the one hand, exchange rate appreciation lowers trade competitiveness but, on the other hand, it also reduces the stock of external and domestic dollar-denominated debt. As such, the effect of REER on risk premium is ambiguous. Sovereign debt crisis and banking crisis dummies may positively affect bond spread, since a government's borrowing costs should increase in times of financial stress. The inflation rate is expected to increase bond spread, because high inflation rates might signal unhealthy macroeconomic fundamentals and higher economic uncertainty. Trade openness (measured as the sum of exports and imports in $\%$ of GDP) could decrease the probability of external default. Finally, Sovereign debt rating

\footnotetext{
${ }^{5}$ Following Frankel et al. (2013), we build an index of institutional quality equal to the average of four normalized variables, namely investment profile, corruption, law and order and bureaucratic quality.
} 
(computed as the average of long-term foreign currency debt rating provided by Standard and Poor's, Moody's, and Fitch) may reduce risk premiums, since higher rating grades usually signal better macroeconomic performance. Appendices 1 and 2 present the sources and definitions of variables, and the descriptive statistics, respectively.

\subsection{Identification strategy}

The main challenge of this study is to identify the appropriate parameter of interest $\beta_{1}$ in equation (1) above, given the potential issue of endogeneity. Indeed, remittances may be endogenous for three reasons. First, there may be a simultaneity bias running from remittances to bond spread and vice versa. For instance, if remittances can reduce bond spread, as discussed in the introduction, worsening conditions of access to financial markets can also affect fiscal policy management, for example, through a reduction of social transfers or operating expenditures. More generally, a tightening of a government's borrowing constraint can lead to procyclical fiscal policy (Galvin and Perotti, 1997). In such circumstances, one would assume that migrants would remit more money in order to support their families back home, which raises the issue of simultaneity bias. Second, data on remittances suffers from measurement errors, with unrecorded remittances accounting for $20 \%$ to $200 \%$ of recorded remittances (Freund and Spatafora, 2008). Moreover, as recently pointed out by Clemens and McKenzie (2014), much of the recent rise in measured remittances may be illusory, arising from changes in measurement rather than changes in real financial flows. Third, there may be an omitted variable bias since we cannot be sure that we control for all factors that affect both remittances and bond spreads.

Our strategy to mitigate these endogeneity issues is to identify an external instrument for remittances. ${ }^{6}$ In our benchmark analysis, we use the potential earning in migrants' host countries as an external instrument for remittances. The potential earning in migrants' host countries is proxied by real GDP per capita of the country of destination of migrants weighted by the share of emigrants of the host country. The underlying idea is that remittances sent home are positively related to the economic conditions in migrants' countries of residence. However, there is no reason to suspect a direct link between the originating country's bond spreads and the economic conditions in migrants' countries of residence after controlling for international business cycle transmission through the variables of trade openness, capital

\footnotetext{
${ }^{6}$ As pointed by an anonymous referee, a recurrent theme in the literature on remittances is the lack of quality of the instrumental variables used. Consequently, we employ a large set of robustness checks in the empirical section to assess the quality of our findings.
} 
account openness and financial crises. In a robustness check, we also consider the possible inertia in the evolution of government risk premiums and employ a system-GMM estimator. In addition to the traditional system-GMM, we propose an augmented system-GMM using our instrument to increase the efficiency of the estimates

\section{Results}

We begin by presenting our baseline results and then explore the robustness of our findings.

\subsection{Baseline results}

Table 1 presents the results based on simple OLS. We start with a parsimonious specification with only remittances as an explanatory variable in column [1], and then bring the control

Table 1. Remittances and Sovereign Bond Yield Spreads (Fixed-effect results).

\begin{tabular}{|c|c|c|c|}
\hline & [1] & {$[2]$} & [3] \\
\hline Log Remittance-to-GDP & $\begin{array}{c}-0.0541 \\
(0.0793)\end{array}$ & $\begin{array}{c}-0.0208 \\
(0.0517)\end{array}$ & $\begin{array}{c}-0.0515 \\
(0.0440)\end{array}$ \\
\hline Log Trade openness-to-GDP & & $\begin{array}{c}-0.5399 \\
(0.3342)\end{array}$ & $\begin{array}{c}0.0342 \\
(0.3194)\end{array}$ \\
\hline Real GDP growth & & $\begin{array}{c}-0.0518 * * * \\
(0.0074)\end{array}$ & $\begin{array}{c}-0.0498 * * * \\
(0.0078)\end{array}$ \\
\hline Log Total government debt-to-GDP & & $\begin{array}{c}0.6515 * * * \\
(0.1475)\end{array}$ & $\begin{array}{l}0.2586^{*} \\
(0.1519)\end{array}$ \\
\hline Government fiscal deficit-to-GDP & & $\begin{array}{l}-0.0000 \\
(0.0162)\end{array}$ & $\begin{array}{c}-0.0067 \\
(0.0168)\end{array}$ \\
\hline Log Total external reserves-to-GDP & & $\begin{array}{c}-0.3485 * * * \\
(0.1026)\end{array}$ & $\begin{array}{c}-0.1511 \\
(0.0938)\end{array}$ \\
\hline Institutional quality & & $\begin{array}{c}-0.5451 \\
(0.8660)\end{array}$ & $\begin{array}{c}0.3030 \\
(0.8801)\end{array}$ \\
\hline Current account balance-to-GDP & & $\begin{array}{c}0.0077 \\
(0.0120)\end{array}$ & $\begin{array}{c}0.0047 \\
(0.0124)\end{array}$ \\
\hline Log Real effective exchange rate & & $\begin{array}{l}-0.4048 \\
(0.3072)\end{array}$ & $\begin{array}{c}0.3355 \\
(0.3514)\end{array}$ \\
\hline Sovereign debt crisis & & $\begin{array}{c}0.4036 * * * \\
(0.0941)\end{array}$ & $\begin{array}{c}0.2993 * * * \\
(0.0811)\end{array}$ \\
\hline Banking crisis & & $\begin{array}{c}0.3848 * * * \\
(0.1254)\end{array}$ & $\begin{array}{c}0.2032 * * \\
(0.0837)\end{array}$ \\
\hline Inflation rate & & $\begin{array}{c}0.0001 \\
(0.0001)\end{array}$ & $\begin{array}{c}0.0000 \\
(0.0001)\end{array}$ \\
\hline Sovereign debt rating & & & $\begin{array}{c}-0.1906 * * * \\
(0.0311)\end{array}$ \\
\hline Constant & $\begin{array}{c}5.7933 * * * \\
(0.0028)\end{array}$ & $\begin{array}{c}7.2852 * * * \\
(2.2017)\end{array}$ & $\begin{array}{c}4.6504 * * \\
(1.9078)\end{array}$ \\
\hline Observations & 504 & 440 & 430 \\
\hline R-squared & 0.0036 & 0.4519 & 0.5153 \\
\hline Number of countries & 38 & 38 & 38 \\
\hline Country fixed effects & Yes & Yes & Yes \\
\hline
\end{tabular}


variables into the regressions in columns [2] and [3]. At the outset, it is worth noting that sovereign debt rating is highly correlated with most of the country macroeconomic variables. For this reason, we present the results without and with sovereign ratings in columns [2] and [3] respectively, and consider the regression in column [2] as our benchmark specification. Whatever the specification, the estimated effect of remittances is not statistically different from zero. However, as discussed in the previous section, the results from OLS might be biased toward zero given the potential reverse causality between bond spreads and remittances, and subject to other endogeneity issues.

Table 2. Remittances and Sovereign Bond Yield Spreads (IV results).

\begin{tabular}{|c|c|c|c|}
\hline & {$[1]$} & {$[2]$} & [3] \\
\hline Log Remittance-to-GDP & $\begin{array}{c}-0.9166 * * * \\
(0.1740)\end{array}$ & $\begin{array}{c}-0.3511 * * * \\
(0.1313)\end{array}$ & $\begin{array}{c}-0.2679 * * \\
(0.1135)\end{array}$ \\
\hline Log Trade openness-to-GDP & & $\begin{array}{l}-0.3621 \\
(0.3080)\end{array}$ & $\begin{array}{c}0.1710 \\
(0.2956)\end{array}$ \\
\hline Real GDP growth & & $\begin{array}{c}-0.0480 * * * \\
(0.0091)\end{array}$ & $\begin{array}{c}-0.0469 * * * \\
(0.0076)\end{array}$ \\
\hline Log Total government debt-to-GDP & & $\begin{array}{c}0.6286^{* * * *} \\
(0.1148)\end{array}$ & $\begin{array}{c}0.2403 * * \\
(0.0987)\end{array}$ \\
\hline Government fiscal deficit-to-GDP & & $\begin{array}{l}-0.0016 \\
(0.0148)\end{array}$ & $\begin{array}{l}-0.0082 \\
(0.0131)\end{array}$ \\
\hline Log Total external reserves-to-GDP & & $\begin{array}{c}-0.2088 * * \\
(0.0922)\end{array}$ & $\begin{array}{l}-0.0361 \\
(0.1031)\end{array}$ \\
\hline Institutional quality & & $\begin{array}{c}-1.7660 * * \\
(0.7976)\end{array}$ & $\begin{array}{l}-0.4615 \\
(0.7897)\end{array}$ \\
\hline Current account balance-to-GDP & & $\begin{array}{l}-0.0021 \\
(0.0117)\end{array}$ & $\begin{array}{l}-0.0046 \\
(0.0124)\end{array}$ \\
\hline Log Real effective exchange rate & & $\begin{array}{c}-0.6059 * * * \\
(0.1971)\end{array}$ & $\begin{array}{c}0.2682 \\
(0.2389)\end{array}$ \\
\hline Sovereign debt crisis & & $\begin{array}{c}0.5085 * * * \\
(0.1142)\end{array}$ & $\begin{array}{c}0.3688 * * * \\
(0.1237)\end{array}$ \\
\hline Banking crisis & & $\begin{array}{c}0.4003 * * * \\
(0.0896)\end{array}$ & $\begin{array}{c}0.1893 * * * \\
(0.0668)\end{array}$ \\
\hline Inflation rate & & $\begin{array}{c}0.0001 \\
(0.0002)\end{array}$ & $\begin{array}{c}0.0000 \\
(0.0002)\end{array}$ \\
\hline Sovereign debt rating & & & $\begin{array}{c}-0.2115^{* * * *} \\
(0.0315)\end{array}$ \\
\hline & \multicolumn{3}{|c|}{ First stage regressions for instrumentation } \\
\hline Log - Real GDP per capita in host countries & $\begin{array}{c}3.3974 * * * \\
(0.4456)\end{array}$ & $\begin{array}{c}3.3534 * * * \\
(0.7768)\end{array}$ & $\begin{array}{c}3.3629 * * * \\
(0.7802)\end{array}$ \\
\hline Observations & 504 & 440 & 430 \\
\hline R-squared & 0.0536 & $\begin{array}{c}0.3545 \\
18.64\end{array}$ & $\begin{array}{c}0.4751 \\
18.58\end{array}$ \\
\hline F-stat remittance instrumentation [p-value] & $58.11[0.00]$ & {$[0.00]$} & {$[0.00]$} \\
\hline Number of countries & 38 & 38 & 38 \\
\hline Country fixed effects & Yes & Yes & Yes \\
\hline
\end{tabular}

To deal with the endogeneity issue, Table 2 replicates the results from Table 1 using the potential earning in migrants' host countries as an external instrument for remittances. In 
each regression, we report the first stage results of the instrumental variable approach. It appears that our instrument is highly statistically significant and with the expected signs. We find that GDP per capita in migrants' host countries is positively correlated with remittances. In addition, the F-tests of the first stage regressions for remittances are higher than 10, with respect to the golden rule of Staiger and Stock (1997). We can therefore conclude that our instrument for remittances is relevant. However, we are not able to test explicitly the validity of the instrumental variable approach, given that we have only one instrument for remittances. We then turn to the results of our main variable of interest.

In Table 2, all the estimated coefficients of remittances are negative and statistically significant. The size of these coefficients lies between -0.92 and -0.27 percent. This result is economically meaningful: a 1 percentage increase in remittances-to-GDP leads to 0.27 to 0.92 percentage fall in bond yield spreads. Given that the average borrowing cost in our sample of emerging market countries is approximately 500 basis points (see Appendix 2), in concrete terms this means that an increase of 1 percent of remittances-to-GDP inflows decreases sovereign debt risk premia by about 3 basis points.

To summarize, the empirical result reported in Table 2 suggests that remittances negatively affect bond yield spreads. Regarding the control variables, most are statistically significant, with the expected signs. However, some variables lose their statistical significance once sovereign debt rating is introduced in the regressions, probably due to multicollinearity. Consistent with early studies, we find that higher GDP growth, higher exchange reserves, sound institutions and real effective exchange rate appreciation are negatively correlated with bond yield spreads, while higher government debt, banking and debt crises are positive determinants of spreads. The negative coefficient for real effective exchange rates suggests that the balance sheet effect may dominate the competitiveness effect.

\section{2. Robustness tests}

We test the robustness of our findings in different ways. First, we replicate our baseline estimation by replacing the ratio of remittances over GDP by the per capita value. ${ }^{7}$ The underlining idea is to capture the potential variation in intensity of the receiving country's fiscal space resulting from these two types of capital flows. The result reported in column [1] of Table 3 is conclusive, confirming the robustness of our baseline result.

\footnotetext{
7 We also use an alternative definition of the principal variable of interest. More precisely, we replace remittance flows by the sum of workers' remittances, compensation of employees and migrant's transfers. Overall, the result, available upon request, is consistent with our finding in the baseline specification.
} 
Second, we look for the potential role of time-specific factors. For this purpose, we include time dummies in the regression to account for common shocks across countries. ${ }^{8}$ The result is reported in column [2] of Table 3. We find that the effect of remittances on bond yields is not driven by time-specific factors.

Table 3. Remittances and Sovereign Bond Yield Spreads (IV results), Robustness checks.

\begin{tabular}{|c|c|c|c|c|c|}
\hline & $\begin{array}{l}\text { Remittance } \\
\text { per capita }\end{array}$ & $\begin{array}{l}\text { Time fixed- } \\
\text { effects }\end{array}$ & CDS spreads & $\begin{array}{c}\text { Excluding oil } \\
\text { exporting countries }\end{array}$ & $\begin{array}{l}\text { Excluding } \\
2007-2012 \\
\end{array}$ \\
\hline & [1] & {$[2]$} & [3] & {$[4]$} & {$[5]$} \\
\hline Log Remittance per capita & $\begin{array}{c}-0.3307 * * * \\
(0.1219)\end{array}$ & & & & \\
\hline Log Remittance-to-GDP & & $\begin{array}{c}-0.5066^{* *} \\
(0.2179)\end{array}$ & $\begin{array}{c}-0.6120 * * \\
(0.3009)\end{array}$ & $\begin{array}{c}-0.5114 * * \\
(0.2186)\end{array}$ & $\begin{array}{c}-0.4418 * * * \\
(0.1031)\end{array}$ \\
\hline Log Trade openness-to-GDP & $\begin{array}{l}-0.2906 \\
(0.3073)\end{array}$ & $\begin{array}{c}-0.4459 * \\
(0.2476)\end{array}$ & $\begin{array}{c}1.0080 * \\
(0.5430)\end{array}$ & $\begin{array}{c}-0.4661 \\
(0.4227)\end{array}$ & $\begin{array}{l}-0.6114 \\
(0.3854)\end{array}$ \\
\hline Real GDP growth & $\begin{array}{c}-0.0488 * * * \\
(0.0085)\end{array}$ & $\begin{array}{c}-0.0455 * * * \\
(0.0095)\end{array}$ & $\begin{array}{c}-0.0750 * * * \\
(0.0147)\end{array}$ & $\begin{array}{c}-0.0466 * * * \\
(0.0164)\end{array}$ & $\begin{array}{c}-0.0260 * * \\
(0.0116)\end{array}$ \\
\hline Log Total government debt-to-GDP & $\begin{array}{c}0.6576^{* * *} \\
(0.1140)\end{array}$ & $\begin{array}{c}0.6394 * * * \\
(0.1022)\end{array}$ & $\begin{array}{c}0.7594 * * * \\
(0.2697)\end{array}$ & $\begin{array}{c}0.7344 * * * \\
(0.2119)\end{array}$ & $\begin{array}{c}0.8056 * * * \\
(0.1924)\end{array}$ \\
\hline Government fiscal deficit-to-GDP & $\begin{array}{l}-0.0031 \\
(0.0142)\end{array}$ & $\begin{array}{c}0.0016 \\
(0.0121)\end{array}$ & $\begin{array}{c}-0.0407 * * \\
(0.0204)\end{array}$ & $\begin{array}{c}0.0027 \\
(0.0277)\end{array}$ & $\begin{array}{c}0.0122 \\
(0.0186)\end{array}$ \\
\hline Log Total external reserves-to-GDP & $\begin{array}{l}-0.1721 * \\
(0.0975)\end{array}$ & $\begin{array}{l}-0.2142 * \\
(0.1105)\end{array}$ & $\begin{array}{l}-0.0246 \\
(0.2308)\end{array}$ & $\begin{array}{l}-0.0415 \\
(0.1336)\end{array}$ & $\begin{array}{l}-0.2171 * \\
(0.1154)\end{array}$ \\
\hline Institutional quality & $\begin{array}{l}-1.0864 * \\
(0.6383)\end{array}$ & $\begin{array}{c}-2.0910 * * \\
(0.9934)\end{array}$ & $\begin{array}{l}-3.0877 \\
(2.2643)\end{array}$ & $\begin{array}{l}-2.4020 * \\
(1.3830)\end{array}$ & $\begin{array}{l}-1.5148 * \\
(0.8125)\end{array}$ \\
\hline Current account balance-to-GDP & $\begin{array}{l}-0.0017 \\
(0.0115)\end{array}$ & $\begin{array}{l}-0.0060 \\
(0.0099)\end{array}$ & $\begin{array}{c}0.0043 \\
(0.0133)\end{array}$ & $\begin{array}{c}-0.0119 \\
(0.0191)\end{array}$ & $\begin{array}{l}-0.0003 \\
(0.0111)\end{array}$ \\
\hline Log Real effective exchange rate & $\begin{array}{l}-0.2391 \\
(0.2056)\end{array}$ & $\begin{array}{c}-0.8282 * * * \\
(0.3179)\end{array}$ & $\begin{array}{c}-1.1040 * \\
(0.6273)\end{array}$ & $\begin{array}{c}-0.7416^{* * * *} \\
(0.2628)\end{array}$ & $\begin{array}{c}-1.5957 * * * \\
(0.2950)\end{array}$ \\
\hline Sovereign debt crisis & $\begin{array}{c}0.5278 * * * \\
(0.1113)\end{array}$ & $\begin{array}{c}0.5828 * * * \\
(0.1691)\end{array}$ & $\begin{array}{c}0.4085 \\
(0.3484)\end{array}$ & $\begin{array}{c}0.7295 * * * \\
(0.2167)\end{array}$ & $\begin{array}{c}0.4682 * * * \\
(0.1184)\end{array}$ \\
\hline Banking crisis & $\begin{array}{c}0.3909 * * * \\
(0.0857)\end{array}$ & $\begin{array}{c}0.4542 * * * \\
(0.1139)\end{array}$ & $\begin{array}{c}0.8259 * * * \\
(0.2141)\end{array}$ & $\begin{array}{c}0.4968 * * * \\
(0.1248)\end{array}$ & $\begin{array}{c}0.2967 * * * \\
(0.0935)\end{array}$ \\
\hline Inflation rate & $\begin{array}{c}0.0002 \\
(0.0003) \\
\end{array}$ & $\begin{array}{c}0.0001 \\
(0.0003) \\
\end{array}$ & $\begin{array}{c}0.0290 \\
(0.0183) \\
\end{array}$ & $\begin{array}{c}-0.0008 * * \\
(0.0004) \\
\end{array}$ & $\begin{array}{l}-0.0000 \\
(0.0003) \\
\end{array}$ \\
\hline & \multicolumn{5}{|c|}{ First stage regressions for instrumentation } \\
\hline Log - Real GDP per capita in host countries & $\begin{array}{c}3.4923 * * * \\
(0.7896)\end{array}$ & $\begin{array}{c}3.1421 * * * \\
(0.7265)\end{array}$ & $\begin{array}{c}2.9349 * * * \\
(0.8163)\end{array}$ & $\begin{array}{c}2.9277 * * * \\
(0.9698)\end{array}$ & $\begin{array}{c}5.6237 * * * \\
(0.8010)\end{array}$ \\
\hline Observations & 434 & 440 & 127 & 320 & 257 \\
\hline R-squared & 0.3938 & 0.2458 & 0.5186 & 0.1045 & 0.4703 \\
\hline F-stat remittance instrumentation [p-value] & $19.56[0.00]$ & $18.70[0.00]$ & $15.01[0.00]$ & $9.11[0.00]$ & $49.29[0.00]$ \\
\hline Number of countries & 38 & 38 & 17 & 29 & 31 \\
\hline Country fixed effects & Yes & Yes & Yes & Yes & Yes \\
\hline
\end{tabular}

Note: Robust standard errors in parentheses. $* * * \mathrm{p}<0.01, * * \mathrm{p}<0.05, * \mathrm{p}<0.1$.

\footnotetext{
${ }^{8}$ Including time dummies removes US bond yield from the left-hand side of the estimated equation. As a result, the dependent variable in column [2] is no longer bond yield spread but rather bond yield.
} 
Next, in column [3] of Table 3, we use an alternative proxy of government borrowing costs, namely credit default swap (CDS) spreads. Indeed, if the bond market and CDS market are fully integrated and arbitrage takes place, the price of the credit risk in the two markets should follow the similar patterns [see Zhu (2006), for an empirical comparison of credit spreads between the bond and CDS markets). Despite a significant reduction in the number of observations due to the limitation data availability on CDS spreads, our results are remarkably robust to the use of CDS spreads. We find that remittances significantly reduce CDS spreads.

Fourth, we alter the sample in two ways. In column [4] of Table 3, we exclude top oil exporting countries to isolate the specific impact of these countries. ${ }^{9}$ In column [5] of Table 3 , we exclude the post-2006 period to isolate the potential influence of the 2007 crisis, that is the well-known global savings glut and the recent post-crisis quantitative easing measures. We find that, after altering the sample, our main conclusion does not change.

The next step consists of controlling for other determinants of spreads to make sure that our result is not driven by the specific choice of the control variables introduced in the regressions. To do so, we consider other relevant determinants of bond yield spreads found in previous literature. These additional factors include an IMF lending program dummy, real GDP per capita (a proxy for the level of economic development), capital account openness (measured by the Chinn-Ito Index), the unemployment rate (in \% of labor force), a currency crisis dummy, credit to private sector (in \% of GDP, as a measure of the level of financial development), the stock of immigrants, and monetary damage from natural disasters. The results are reported in Table 4. Irrespective of the specification, the results remain consistent, adding to the robustness of the benchmark results.

Finally, we consider possible inertia in the evolution of government risk premiums and employ a system-GMM estimator. In addition to the traditional system-GMM, we also propose an augmented system-GMM using our external instrument to increase the efficiency of the estimates. The results are presented in columns [1] and [2] of Table 5 for traditional system-GMM and augmented system-GMM-IV, respectively. Before going to the interpretation of the estimated coefficients, we submit the regressions to the traditional three diagnostic tests: the Hansen test for overidentifying restrictions and the Arellano-Bond tests for first and second order serial correlation. As reported in Table 5, the results of the Hansen test and serial correlation tests are conclusive-we find a first order serial correlation but not a

\footnotetext{
${ }^{9}$ We excluded OPEC and countries in top 15 world oil net exporters from the 2012 U.S. Energy Information Administration classification.
} 
second one, and the overidentifying restrictions are also valid. More importantly, the estimated coefficient 
Table 4. Remittances and Sovereign Bond Yield Spreads (IV results), Robustness checks.

\begin{tabular}{|c|c|c|c|c|c|c|c|c|}
\hline & [1] & {$[2]$} & [3] & [4] & [5] & [6] & [7] & [8] \\
\hline Log Remittance-to-GDP & $\begin{array}{c}-0.3499 * * * \\
(0.1323)\end{array}$ & $\begin{array}{c}-0.3291 * * * \\
(0.1248)\end{array}$ & $\begin{array}{c}-0.3585 * * * \\
(0.1349)\end{array}$ & $\begin{array}{c}-0.3330 * * * \\
(0.1292)\end{array}$ & $\begin{array}{c}-0.3599 * * \\
(0.1397)\end{array}$ & $\begin{array}{l}-0.1829 * \\
(0.0950)\end{array}$ & $\begin{array}{l}-0.4944 * \\
(0.2871)\end{array}$ & $\begin{array}{c}-0.3496^{* * *} \\
(0.1320)\end{array}$ \\
\hline Log Trade openness-to-GDP & $\begin{array}{l}-0.3609 \\
(0.3103)\end{array}$ & $\begin{array}{l}-0.3431 \\
(0.3081)\end{array}$ & $\begin{array}{l}-0.3172 \\
(0.3225)\end{array}$ & $\begin{array}{l}-0.3493 \\
(0.3017)\end{array}$ & $\begin{array}{l}-0.3526 \\
(0.3146)\end{array}$ & $\begin{array}{l}-0.1991 \\
(0.2731)\end{array}$ & $\begin{array}{l}-0.4445 \\
(0.2791)\end{array}$ & $\begin{array}{l}-0.3789 \\
(0.3115)\end{array}$ \\
\hline Real GDP growth & $\begin{array}{c}-0.0479 * * * \\
(0.0090)\end{array}$ & $\begin{array}{l}-0.0287 \\
(0.0195)\end{array}$ & $\begin{array}{c}-0.0487 * * * \\
(0.0091)\end{array}$ & $\begin{array}{c}-0.0471^{* * *} * \\
(0.0090)\end{array}$ & $\begin{array}{c}-0.0490 * * * \\
(0.0084)\end{array}$ & $\begin{array}{c}-0.0587 * * * \\
(0.0075)\end{array}$ & $\begin{array}{c}-0.0456 * * * \\
(0.0124)\end{array}$ & $\begin{array}{c}-0.0479 * * * \\
(0.0091)\end{array}$ \\
\hline Log Total government debt-to-GDP & $\begin{array}{c}0.6074 * * * \\
(0.1571)\end{array}$ & $\begin{array}{c}0.6278^{* * *} \\
(0.1154)\end{array}$ & $\begin{array}{c}0.6179 * * * \\
(0.1159)\end{array}$ & $\begin{array}{c}0.6082^{* * *} \\
(0.1192)\end{array}$ & $\begin{array}{c}0.6274 * * * \\
(0.1144)\end{array}$ & $\begin{array}{c}0.5661 * * * \\
(0.1037)\end{array}$ & $\begin{array}{c}0.6425^{* * *} \\
(0.1278)\end{array}$ & $\begin{array}{c}0.6301 * * * \\
(0.1147)\end{array}$ \\
\hline Government fiscal deficit-to-GDP & $\begin{array}{l}-0.0019 \\
(0.0153)\end{array}$ & $\begin{array}{l}-0.0008 \\
(0.0146)\end{array}$ & $\begin{array}{c}0.0002 \\
(0.0149)\end{array}$ & $\begin{array}{l}-0.0026 \\
(0.0146)\end{array}$ & $\begin{array}{l}-0.0017 \\
(0.0147)\end{array}$ & $\begin{array}{l}-0.0055 \\
(0.0134)\end{array}$ & $\begin{array}{c}0.0018 \\
(0.0150)\end{array}$ & $\begin{array}{l}-0.0010 \\
(0.0149)\end{array}$ \\
\hline Log Total external reserves-to-GDP & $\begin{array}{c}-0.2051 * * \\
(0.0903)\end{array}$ & $\begin{array}{c}-0.2076^{* * *} \\
(0.0929)\end{array}$ & $\begin{array}{c}-0.1980^{* * *} \\
(0.0953)\end{array}$ & $\begin{array}{c}-0.2069 * * \\
(0.0915)\end{array}$ & $\begin{array}{c}-0.2207 * * \\
(0.0863)\end{array}$ & $\begin{array}{c}-0.1765^{* *} \\
(0.0849)\end{array}$ & $\begin{array}{c}-0.2162^{* *} \\
(0.0981)\end{array}$ & $\begin{array}{c}-0.2042 * * \\
(0.0932)\end{array}$ \\
\hline Institutional quality & $\begin{array}{c}-1.8142 * * \\
(0.8383)\end{array}$ & $\begin{array}{c}-1.7370 * * \\
(0.7838)\end{array}$ & $\begin{array}{c}-1.7378^{* *} \\
(0.7916)\end{array}$ & $\begin{array}{c}-1.6812 * * \\
(0.7855)\end{array}$ & $\begin{array}{c}-1.7431 * * \\
(0.7883)\end{array}$ & $\begin{array}{c}-1.3651 * * \\
(0.6937)\end{array}$ & $\begin{array}{l}-2.0667 * \\
(1.0994)\end{array}$ & $\begin{array}{c}-1.8097 * * \\
(0.7940)\end{array}$ \\
\hline Current account balance-to-GDP & $\begin{array}{l}-0.0021 \\
(0.0118)\end{array}$ & $\begin{array}{l}-0.0019 \\
(0.0116)\end{array}$ & $\begin{array}{l}-0.0028 \\
(0.0119)\end{array}$ & $\begin{array}{l}-0.0026 \\
(0.0116)\end{array}$ & $\begin{array}{l}-0.0025 \\
(0.0119)\end{array}$ & $\begin{array}{l}-0.0039 \\
(0.0112)\end{array}$ & $\begin{array}{l}-0.0057 \\
(0.0160)\end{array}$ & $\begin{array}{l}-0.0019 \\
(0.0118)\end{array}$ \\
\hline Log Real effective exchange rate & $\begin{array}{c}-0.6089 * * * \\
(0.1983)\end{array}$ & $\begin{array}{c}-0.6212 * * * \\
(0.1992)\end{array}$ & $\begin{array}{c}-0.5617 * * * \\
(0.1988)\end{array}$ & $\begin{array}{c}-0.6018 * * * \\
(0.1962)\end{array}$ & $\begin{array}{c}-0.6392 * * * \\
(0.2052)\end{array}$ & $\begin{array}{l}-0.2100 \\
(0.2064)\end{array}$ & $\begin{array}{c}-0.8187 * * \\
(0.3620)\end{array}$ & $\begin{array}{c}-0.6183^{* * * *} \\
(0.1949)\end{array}$ \\
\hline Sovereign debt crisis & $\begin{array}{c}0.5053 * * * \\
(0.1145)\end{array}$ & $\begin{array}{c}0.5006^{* * *} \\
(0.1122)\end{array}$ & $\begin{array}{c}0.5038^{* * * *} \\
(0.1152)\end{array}$ & $\begin{array}{c}0.5021 \text { *** } \\
(0.1141)\end{array}$ & $\begin{array}{c}0.5278 * * * \\
(0.1231)\end{array}$ & $\begin{array}{c}0.4508 * * * \\
(0.1125)\end{array}$ & $\begin{array}{c}0.5764 * * * \\
(0.1572)\end{array}$ & $\begin{array}{c}0.5109 * * * \\
(0.1146)\end{array}$ \\
\hline Banking crisis & $\begin{array}{c}0.3902 * * * \\
(0.0984)\end{array}$ & $\begin{array}{c}0.3978 * * * \\
(0.0893)\end{array}$ & $\begin{array}{c}0.4031 \text { *** } \\
(0.0905)\end{array}$ & $\begin{array}{c}0.3917 * * * \\
(0.0886)\end{array}$ & $\begin{array}{c}0.4160 \text { *** } \\
(0.0982)\end{array}$ & $\begin{array}{c}0.4677 * * * \\
(0.0809)\end{array}$ & $\begin{array}{c}0.4502^{* * * *} \\
(0.1382)\end{array}$ & $\begin{array}{c}0.4024 * * * \\
(0.0901)\end{array}$ \\
\hline Inflation rate & $\begin{array}{c}0.0001 \\
(0.0002)\end{array}$ & $\begin{array}{c}0.0001 \\
(0.0002)\end{array}$ & $\begin{array}{c}0.0001 \\
(0.0002)\end{array}$ & $\begin{array}{c}0.0001 \\
(0.0002)\end{array}$ & $\begin{array}{c}0.0001 \\
(0.0002)\end{array}$ & $\begin{array}{c}0.0001 \\
(0.0003)\end{array}$ & $\begin{array}{c}0.0001 \\
(0.0003)\end{array}$ & $\begin{array}{c}0.0001 \\
(0.0002)\end{array}$ \\
\hline IMF program & $\begin{array}{c}0.0523 \\
(0.1520)\end{array}$ & & & & & & & \\
\hline Log GDP per capita & & $\begin{array}{l}-1.9300 \\
(1.5605)\end{array}$ & & & & & & \\
\hline Financial openness (Kaopen) & & & $\begin{array}{l}-0.0398 \\
(0.0345)\end{array}$ & & & & & \\
\hline Unemployment rate & & & & $\begin{array}{c}0.0110 \\
(0.0151)\end{array}$ & & & & \\
\hline Currency crisis & & & & & $\begin{array}{l}-0.0961 \\
(0.1401)\end{array}$ & & & \\
\hline Log Private credit-to-GDP & & & & & & $\begin{array}{c}-0.4164 * * * \\
(0.1123)\end{array}$ & & \\
\hline Log Total migrants & & & & & & & $\begin{array}{c}0.7299 \\
(0.9865)\end{array}$ & \\
\hline \multirow[t]{2}{*}{ Log Natural disaster damage } & & & & & & & & $\begin{array}{c}0.0062 \\
(0.0063)\end{array}$ \\
\hline & \multicolumn{8}{|c|}{ First stage regressions for instrumentation } \\
\hline Log - Real GDP per capita in host countries & $\begin{array}{c}3.3467 * * * \\
(0.7823)\end{array}$ & $\begin{array}{c}3.4557 * * * \\
(0.7630)\end{array}$ & $\begin{array}{c}3.2808 * * * \\
(0.7841)\end{array}$ & $\begin{array}{c}3.4855 * * * \\
(0.8273)\end{array}$ & $\begin{array}{c}3.2377 * * * \\
(0.8170)\end{array}$ & $\begin{array}{c}3.9630 * * * \\
(0.5542)\end{array}$ & $\begin{array}{c}3.1745^{* *} \\
(1.4168)\end{array}$ & $\begin{array}{c}3.3573 * * * \\
(0.7731)\end{array}$ \\
\hline Observations & 440 & 439 & 440 & 440 & 440 & 440 & 440 & 440 \\
\hline R-squared & 0.3558 & 0.3695 & 0.3515 & 0.3656 & 0.3508 & 0.4490 & 0.2560 & 0.3573 \\
\hline F-stat remittance instrumentation [p-value] & $18.30[0.00]$ & $20.51[0.00]$ & $17.50[0.00]$ & $17.75[0.00]$ & $15.70[0.00]$ & $51.12[0.00]$ & $5.02[0.02]$ & $18.86[0.00]$ \\
\hline Number of countries & 38 & 38 & 38 & 38 & 38 & 38 & 38 & 38 \\
\hline Country fixed effects & Yes & Yes & Yes & Yes & Yes & Yes & Yes & Yes \\
\hline
\end{tabular}

Note: Robust standard errors in parentheses. *** $\mathrm{p}<0.01, * * \mathrm{p}<0.05, * \mathrm{p}<0.1$. 
Table 5. Remittances and Sovereign Bond Yield Spreads (System GMM and System GMM-IV results).

\begin{tabular}{|c|c|c|}
\hline & System GMM & System GMM-IV \\
\hline & {$[1]$} & {$[2]$} \\
\hline Lag - Log bond yield spreads & $\begin{array}{c}0.5064 * * \\
(0.197)\end{array}$ & $\begin{array}{c}0.5379 * * \\
(0.220)\end{array}$ \\
\hline Log Remittance-to-GDP & $\begin{array}{c}-0.3638 * * \\
(0.180)\end{array}$ & $\begin{array}{c}-0.4326 * * * \\
(0.126)\end{array}$ \\
\hline Log Trade openness-to-GDP & $\begin{array}{l}0.2897 \\
(0.694)\end{array}$ & $\begin{array}{l}0.1399 \\
(0.979)\end{array}$ \\
\hline Real GDP growth & $\begin{array}{c}-0.0371 * \\
(0.021)\end{array}$ & $\begin{array}{c}-0.0406 * \\
(0.023)\end{array}$ \\
\hline Log Total government debt-to-GDP & $\begin{array}{l}0.1353 \\
(0.224)\end{array}$ & $\begin{array}{l}0.1782 \\
(0.239)\end{array}$ \\
\hline Government fiscal deficit-to-GDP & $\begin{array}{l}0.0127 \\
(0.052)\end{array}$ & $\begin{array}{l}0.0268 \\
(0.060)\end{array}$ \\
\hline Log Total external reserves-to-GDP & $\begin{array}{l}-0.2003 \\
(0.327)\end{array}$ & $\begin{array}{l}-0.0537 \\
(0.298)\end{array}$ \\
\hline Institutional quality & $\begin{array}{r}-0.8456 \\
(2.627)\end{array}$ & $\begin{array}{c}-1.4068 \\
(3.243)\end{array}$ \\
\hline Current account balance-to-GDP & $\begin{array}{l}-0.0419 \\
(0.048)\end{array}$ & $\begin{array}{r}-0.0532 \\
(0.054)\end{array}$ \\
\hline Log Real effective exchange rate & $\begin{array}{l}0.2151 \\
(0.539)\end{array}$ & $\begin{array}{l}0.0796 \\
(0.508)\end{array}$ \\
\hline Sovereign debt crisis & $\begin{array}{c}1.3456 * * * \\
(0.509)\end{array}$ & $\begin{array}{c}1.3743 * * * \\
(0.446)\end{array}$ \\
\hline Banking crisis & $\begin{array}{l}0.1442 \\
(0.399)\end{array}$ & $\begin{array}{l}0.0668 \\
(0.572)\end{array}$ \\
\hline Inflation rate & $\begin{array}{l}0.0013 \\
(0.006)\end{array}$ & $\begin{array}{l}0.0011 \\
(0.006)\end{array}$ \\
\hline Constant & $\begin{array}{l}0.1083 \\
(4.965)\end{array}$ & $\begin{array}{l}1.5756 \\
(6.942)\end{array}$ \\
\hline Observations & 410 & 410 \\
\hline Number of instruments & 24 & 25 \\
\hline $\operatorname{AR}(1)$ & 0.01 & 0.01 \\
\hline AR (2) & 0.13 & 0.12 \\
\hline Hansen J statistic (p-value) & 0.671 & 0.797 \\
\hline Number of countries & 38 & 38 \\
\hline Country fixed effects & Yes & Yes \\
\hline
\end{tabular}

Note: Robust standard errors in parentheses. $* * * \mathrm{p}<0.01, * * \mathrm{p}<0.05,{ }^{*} \mathrm{p}<0.1$.

associated to remittances remains remarkably significant and of comparable magnitude to the benchmark result in Table 2. Consequently, using an alternative identification strategy confirms our previous finding.

All in all, we find that our results are robust to a wide set of robustness checks. In the following section, we analyze heterogeneity of the effect of remittances on bond spreads. 


\section{Heterogeneity on the effect of remittances}

Our analysis presented thus far shows that remittances significantly reduce bond yield spreads in emerging market countries. But is this effect similar in all emerging market countries, regardless of their structural characteristics? To answer this question, we condition the effect of remittances on the degree of financial development, trade openness and fiscal space. To do so, we employ both an endogenous and an exogenous threshold model to split country-year observations into two groups, depending on the degree of financial development, trade openness and fiscal space. We also test the countercyclical relationship explicitly and provide potential heterogeneity for remittance-dependent countries.

\subsection{Remittances and financial development}

We first condition the effect of remittances on financial development. More specifically, we estimate equation 1 for two groups of countries: (i) those with a high degree of financial development; and (ii) those with a low degree of financial development. We proxy the level of financial development by the ratio of domestic credit to private sector over GDP. As stated before, we split the sample in two ways in order to evaluate the consistency of the results obtained. As a first step, the median level of financial development (30.91\%) is used as an exogenous threshold value. In a second step, we follow Hansen (2000) and estimate an endogenous threshold value of financial development of $20.63 \%$. This endogenous threshold is fairly close to the estimated value of Giuliano and Ruiz-Arranz (2009) and Combes and Ebeke (2011).

There are three main reasons why the degree of financial development may affect the effect of remittances on sovereign risk premia differently. First, existing studies suggest that the countercyclical nature of remittances depends on the degree of financial development of the receiving country. More specifically, remittances are more countercyclical in countries with less developed financial systems. Indeed, because of credit market failures in their countries of origin, migrants worry more about protecting their families left behind in their home country, particularly when it faces negative shocks. Consequently, remittances can insure against different types of macroeconomic shocks and more significantly if financial development is low. Second, existing studies suggest that remittances are substitutes for promoting economic activities in countries where the credit market is inefficient or nonexistent (Giuliano and Ruiz-Arranz, 2009). Thus, remittances increase a country's fiscal space and thereby raise potential government tax revenues. Third, the bond market can serve as a safe investment for migrants in countries with a lower level of financial development. In 
this case, the bonds purchased by migrants enhance bond market liquidity with a potential beneficial effect on liquidity premium. 
Table 6. Remittances and Sovereign Bond Yield Spreads (IV results), Heterogeneity.

\begin{tabular}{|c|c|c|c|c|c|c|c|c|c|c|c|c|}
\hline & \multicolumn{6}{|c|}{ Exogenous Threshold } & \multicolumn{6}{|c|}{ Endogenous Threshold } \\
\hline & \multicolumn{2}{|c|}{ [1] Financial development } & \multicolumn{2}{|c|}{ [2] Trade openness } & \multicolumn{2}{|c|}{ [3] Fiscal space } & \multicolumn{2}{|c|}{ [4] Financial development } & \multicolumn{2}{|c|}{ [5] Trade openness } & \multicolumn{2}{|c|}{ [6] Fiscal space } \\
\hline & $<30.91$ & $>=30.91$ & $<61.41$ & $>=61.41$ & $<3.30$ & $>=3.30$ & $<20.63$ & $>=20.63$ & $<50.52$ & $>=50.52$ & $<3.69$ & $>=3.69$ \\
\hline \multirow[t]{2}{*}{ Log Remittance-to-GDP } & $-0.3679 * *$ & -0.3070 & -0.1281 & $-0.4332 * * *$ & -0.2332 & $-1.0024 * *$ & $-0.3814 * *$ & -0.4010 & -0.1423 & $-0.2928 * *$ & -0.1121 & $-0.9211^{*}$ \\
\hline & $(0.1514)$ & $(0.2463)$ & $(0.1414)$ & $(0.1402)$ & $(0.2337)$ & $(0.4275)$ & $(0.1531)$ & $(0.2770)$ & $(0.1484)$ & $(0.1399)$ & $(0.2603)$ & $(0.4739)$ \\
\hline \multirow[t]{2}{*}{ Log Trade openness-to-GDP } & -0.6699 & -0.8927 & & & -0.5473 & -0.9450 & 0.6247 & -0.5902 & & & -0.6476 & -0.7287 \\
\hline & $(0.5292)$ & $(0.8238)$ & & & $(0.4299)$ & $(0.5763)$ & $(0.5963)$ & $(0.4274)$ & & & $(0.4140)$ & $(0.5564)$ \\
\hline \multirow[t]{2}{*}{ Real GDP growth } & $-0.0567 * * *$ & $-0.0568 * * *$ & $-0.0407 * * *$ & $-0.0636^{* * *}$ & $-0.0888 * * *$ & -0.0261 & -0.0214 & $-0.0622 * * *$ & $-0.0332 * * *$ & $-0.0584 * * *$ & $-0.0855 * * *$ & -0.0300 \\
\hline & $(0.0160)$ & $(0.0128)$ & $(0.0107)$ & $(0.0112)$ & $(0.0204)$ & $(0.0194)$ & $(0.0209)$ & $(0.0157)$ & $(0.0126)$ & $(0.0091)$ & $(0.0153)$ & $(0.0189)$ \\
\hline \multirow[t]{2}{*}{ Log Total government debt-to-GDP } & 0.4342 & $0.6535^{* *}$ & $0.6297 * * *$ & $0.6624 * * *$ & & & $1.1512 *$ & $0.6122 * *$ & $1.2374 * * *$ & $0.6699 * * *$ & & \\
\hline & $(0.3517)$ & $(0.3245)$ & $(0.1638)$ & $(0.1880)$ & & & $(0.5974)$ & $(0.2625)$ & $(0.3000)$ & $(0.1690)$ & & \\
\hline \multirow[t]{2}{*}{ Government fiscal deficit-to-GDP } & -0.0110 & 0.0286 & $-0.0264 * *$ & 0.0049 & 0.0068 & -0.0280 & -0.0292 & 0.0215 & -0.0184 & 0.0115 & 0.0092 & -0.0303 \\
\hline & $(0.0226)$ & $(0.0401)$ & $(0.0108)$ & $(0.0179)$ & $(0.0338)$ & $(0.0244)$ & $(0.0247)$ & $(0.0299)$ & $(0.0184)$ & $(0.0191)$ & $(0.0268)$ & $(0.0218)$ \\
\hline \multirow[t]{2}{*}{ Log Total external reserves-to-GDP } & $-0.5559 * * *$ & -0.1060 & $-0.4059 * * *$ & 0.1782 & -0.0388 & $-0.6259 * * *$ & -0.5966 & -0.1379 & $-0.9155^{* * *}$ & $-0.2278 * *$ & -0.0613 & $-0.6246 * * *$ \\
\hline & $(0.1577)$ & $(0.1431)$ & $(0.1134)$ & $(0.1539)$ & $(0.1785)$ & $(0.1997)$ & $(0.5216)$ & $(0.1017)$ & $(0.2215)$ & $(0.1112)$ & $(0.1624)$ & $(0.2031)$ \\
\hline \multirow[t]{2}{*}{ Institutional quality } & -1.2864 & -1.9146 & 0.2859 & $-2.2910^{*}$ & -1.7734 & $-4.0157 * * *$ & -0.4297 & $-1.7683^{*}$ & 0.6802 & -1.2008 & -1.0521 & $-3.5794 * *$ \\
\hline & $(1.0759)$ & $(1.4935)$ & $(0.8153)$ & $(1.3369)$ & $(1.4125)$ & $(1.4831)$ & $(1.9452)$ & $(1.0139)$ & $(1.0365)$ & (1.3348) & $(1.5602)$ & $(1.4307)$ \\
\hline \multirow[t]{2}{*}{ Current account balance-to-GDP } & 0.0158 & 0.0139 & -0.0091 & -0.0027 & 0.0039 & 0.0264 & 0.0060 & -0.0047 & -0.0124 & 0.0074 & 0.0137 & 0.0371 \\
\hline & $(0.0164)$ & $(0.0201)$ & $(0.0136)$ & $(0.0144)$ & $(0.0135)$ & $(0.0253)$ & $(0.0151)$ & $(0.0141)$ & $(0.0215)$ & $(0.0159)$ & $(0.0163)$ & $(0.0278)$ \\
\hline \multirow[t]{2}{*}{ Log Real effective exchange rate } & $-1.4623 * * *$ & 0.4233 & $-0.7639 * * *$ & 0.2013 & $-1.4821 * * *$ & -0.4561 & -0.3013 & -0.4538 & $-0.7104 * * *$ & 0.1550 & $-1.5053 * * *$ & -0.2989 \\
\hline & $(0.3477)$ & $(0.4880)$ & $(0.2435)$ & $(0.4797)$ & $(0.3407)$ & $(0.4756)$ & $(0.3794)$ & $(0.3506)$ & $(0.2560)$ & $(0.4336)$ & $(0.2643)$ & $(0.5051)$ \\
\hline \multirow[t]{2}{*}{ Sovereign debt crisis } & $0.5514 * * *$ & 0.8227 & $0.4125 * * *$ & 0.1183 & 0.2674 & $0.6294 * *$ & 0.2450 & $0.4059 * *$ & $0.4475^{* * *}$ & $0.3588^{* * *}$ & $0.3514 * *$ & $0.6105^{* *}$ \\
\hline & $(0.1551)$ & $(0.7511)$ & $(0.1404)$ & $(0.2085)$ & $(0.2234)$ & $(0.2913)$ & $(0.2887)$ & $(0.1726)$ & $(0.1519)$ & $(0.1632)$ & $(0.1719)$ & $(0.2642)$ \\
\hline \multirow[t]{2}{*}{ Banking crisis } & 0.2055 & $0.5285^{* * *}$ & $0.3174 * * *$ & $0.6701^{* * *}$ & $0.4286^{* * *}$ & -0.1272 & 0.1759 & $0.3773^{* * *}$ & $0.2513^{* * *} *$ & $0.4991 * * *$ & $0.3732 * * *$ & -0.0542 \\
\hline & $(0.1466)$ & $(0.1134)$ & $(0.0956)$ & $(0.1298)$ & $(0.1399)$ & $(0.2129)$ & $(0.2292)$ & $(0.1022)$ & $(0.0945)$ & $(0.1086)$ & $(0.1316)$ & $(0.2247)$ \\
\hline \multirow[t]{2}{*}{ Inflation rate } & $-0.0011^{* * *}$ & 0.0002 & $0.0003^{* *}$ & $-0.0005^{*}$ & 0.0002 & -0.0009 & $-0.0009^{* *}$ & $0.0003 * *$ & $0.0003 * *$ & $-0.0005^{*}$ & 0.0002 & -0.0005 \\
\hline & $(0.0004)$ & $(0.0004)$ & $(0.0001)$ & $(0.0003)$ & $(0.0003)$ & $(0.0006)$ & $(0.0004)$ & $(0.0001)$ & $(0.0001)$ & $(0.0003)$ & $(0.0001)$ & $(0.0006)$ \\
\hline Observations & 193 & 245 & 210 & 231 & 189 & 258 & 85 & 353 & 116 & 324 & 202 & 241 \\
\hline R-squared & 0.4808 & 0.2398 & 0.5290 & 0.3669 & 0.2706 & -0.1004 & 0.5506 & 0.1672 & 0.6739 & 0.4110 & 0.2954 & 0.0265 \\
\hline Number of countries & 22 & 28 & 23 & 29 & 22 & 35 & 14 & 34 & 15 & 33 & 22 & 33 \\
\hline Country fixed effects & Yes & Yes & Yes & Yes & Yes & Yes & Yes & Yes & Yes & Yes & Yes & Yes \\
\hline
\end{tabular}


The results are reported in Table 6. Column [1] uses an exogenous threshold value while column [4] uses an endogenous one. As expected, there is strong evidence that the effect of remittances on government risk premia depends on the level of the country's financial development. The marginal impact of remittances is not statistically different from zero in a highly financially developed regime, independently of the type of threshold used, while remittances have a positive and significant effect in financial underdeveloped regimes.

Overall, the result suggests that the beneficial effect of remittances on a sovereign bond market is obvious in less financially developed countries. Our finding is in line with the work of Giuliano and Ruiz-Arranz (2009).

\subsection{Remittances and trade openness}

In this sub-section, we explore the heterogeneity of the response of bond yield spreads to an increase in remittances by splitting our sample into two groups, depending on the level of trade openness: (i) high degree of openness; (ii) low degree of openness. The main reason is that countries that are more open to trade are relatively more vulnerable to external shocks and also receive more remittances than countries less open to trade. We believe that remittances would be beneficial in countries with more openness to international trade. In those countries, remittances can play an insurance role against external and internal negative shocks and help mitigate the potential adverse effect on bond markets. As is standard in the literature, we proxy trade openness by the ratio of imports, plus exports, over GDP and then estimate an endogenous threshold value of $50.5 \%$ and an exogenous one of $61.41 \%$.

The results of the estimation for the two regimes are reported in column [2] of Table 6 for the exogenous threshold using the median level, and in column [5] of Table 6 for the endogenous threshold. As expected, the beneficial effect of remittances on government borrowing costs occurs in countries with a high degree of trade openness. For countries in the lower trade openness regime, remittances do not seem to have a significant effect on the cost of debt.

\subsection{Remittances and fiscal space}

We also condition the effect of remittances on fiscal space. We proxy fiscal space by the ratio of government debt over total tax revenue (Aizenman et al., 2013) ${ }^{10}$ It is obvious that remittances increase the fiscal space in the receiving economy, whether they are used for current consumption or for investment. Furthermore, previous studies have found that

\footnotetext{
${ }^{10}$ What might be of more value is to measure a country's fiscal space by the distance between current debt levels and the debt limit à la Ostry et al. (2010). However, this is far from the primary interest of this paper.
} 
remittance inflows are higher in highly indebted countries (i.e., in countries with less fiscal space). By increasing fiscal space, we believe that remittances can mitigate "fiscal fatigue" particularly when the ability of the government to raise the primary surplus is restricted. More precisely, we test the hypothesis that the market response to remittance inflows may be apparent only when the country is close to its fiscal capacity. Consequently, we estimate equations (1) for two sub-samples: (i) low fiscal space i.e., when the ratio of government debt over total tax revenue is above a threshold value; and (ii) high fiscal space, using both an exogenous and an endogenous threshold value. ${ }^{11}$

The results are reported in Table 6-column [3] for the exogenous threshold using the median level, and column [6] for the endogenous threshold. Our findings are in line with our expectations: remittances have a significant effect in reducing bond yield spreads when the government's ability to collect taxes in the future is limited, but not any significant effect in high fiscal space standing. More importantly, the magnitude of the estimated coefficient in (i) is greater than in the total sample, meaning that the market attaches foremost importance to remittance inflows in this group. Specifically, a 1 percent increase of remittances received over GDP reduces bond spreads by 1 percent in lower fiscal space countries.

\subsection{Do remittance-dependent countries behave differently?}

In this sub-section, we question whether the market will react differently in remittancedependent countries. We now turn to the heterogeneity based on the dependence on remittances. This is a relevant question, since remittance-dependent countries may be highly vulnerable to global economic turmoil. In some sense, a high level of dependency in a given country could reflect non-diversification of the economy. We believe that bondholders may be more-risk averse in these countries. Moreover, large flows of remittances can have a negative effect on fiscal space through the reduction of the labor supply of recipient households. Furthermore, previous studies find that a high level of remittances can lead to increased corruption (Chami et al., 2008), or Dutch Disease (Bourdet and Falck, 2006; Acosta et al., 2009) or diminish the

Table 7. Remittances and Sovereign Bond Yield Spreads (IV results), Heterogeneity.

\footnotetext{
${ }^{11}$ We estimate an endogenous fiscal space (debt/tax) value of 3.69 and an exogenous threshold of $3.30 \%$.
} 


\begin{tabular}{|c|c|c|}
\hline & [1] & [2] \\
\hline Log Remittance-to-GDP & $\begin{array}{c}-0.2976 * * \\
(0.1300)\end{array}$ & $\begin{array}{l}-2.1803 \\
(1.3567)\end{array}$ \\
\hline Log Trade openness-to-GDP & $\begin{array}{l}-0.0382 \\
(0.2931)\end{array}$ & $\begin{array}{c}-2.4236^{* * * *} \\
(0.8156)\end{array}$ \\
\hline Real GDP growth & $\begin{array}{c}-0.0488 * * * \\
(0.0087)\end{array}$ & $\begin{array}{l}-0.0021 \\
(0.0381)\end{array}$ \\
\hline Log Total government debt-to-GDP & $\begin{array}{c}0.4862 * * * \\
(0.0950)\end{array}$ & $\begin{array}{c}1.3962 * * * \\
(0.5004)\end{array}$ \\
\hline Government fiscal deficit-to-GDP & $\begin{array}{l}-0.0112 \\
(0.0124)\end{array}$ & $\begin{array}{c}0.0306 \\
(0.0384)\end{array}$ \\
\hline Log Total external reserves-to-GDP & $\begin{array}{c}-0.1497 * \\
(0.0894)\end{array}$ & $\begin{array}{c}-0.8946 * * * \\
(0.2751)\end{array}$ \\
\hline Institutional quality & $\begin{array}{c}-2.0361 * * * \\
(0.7850)\end{array}$ & $\begin{array}{l}6.6660 * \\
(3.5214)\end{array}$ \\
\hline Current account balance-to-GDP & $\begin{array}{c}-0.0090 \\
(0.0091)\end{array}$ & $\begin{array}{c}0.0171 \\
(0.0222)\end{array}$ \\
\hline Log Real effective exchange rate & $\begin{array}{c}-0.8066^{* * *} \\
(0.1811)\end{array}$ & $\begin{array}{l}-1.8409 \\
(1.2272)\end{array}$ \\
\hline Sovereign debt crisis & $\begin{array}{c}0.4849 * * * \\
(0.1270)\end{array}$ & $\begin{array}{l}-0.1119 \\
(0.4310)\end{array}$ \\
\hline Banking crisis & $\begin{array}{c}0.4867 * * * \\
(0.1030)\end{array}$ & $\begin{array}{l}-0.7553 \\
(0.4948)\end{array}$ \\
\hline Inflation rate & $\begin{array}{c}0.0001 \\
(0.0001)\end{array}$ & $\begin{array}{l}0.0190 * \\
(0.0103)\end{array}$ \\
\hline Observations & 337 & 102 \\
\hline R-squared & 0.4679 & 0.2437 \\
\hline Number of countries & 29 & 15 \\
\hline Country fixed effects & Yes & Yes \\
\hline
\end{tabular}

stabilizing effect of remittances on consumption and output variation (Chami et al., 2009; Combes and Ebeke, 2011). To test this potential heterogeneity, we divide our sample by quartile depending on the level of remittances received. ${ }^{12}$ We estimate equation (1) for two sub-samples: (i) the top third quartiles; and (ii) the fourth quartile. The average level of remittances received is 3 percent of GDP in the first group and 10 percent in the second. ${ }^{13}$

The results reported in columns [1] and [2] of Table 7 are as follows. In the first group, remittance flows significantly reduce bond yield spreads. However, no statistically significant effect occurs in remittance-dependent countries.

\footnotetext{
${ }^{12}$ We first performed an endogenous threshold model depending on the level of remittances. Unfortunately, this initiative did not lead to interesting results.

${ }^{13} \mathrm{We}$ are aware that this approach is arbitrary. However, we believe that the average level of remittances of 10 percent of GDP in the second group is a good proxy for larger remittances dependency countries. Indeed, Combes and Ebeke (2011) estimated an endogenous threshold value of 6 percent of GDP when studying the effect of remittances on household consumption instability in developing countries.
} 


\section{Conclusion and discussion}

A number of studies have examined the determinants of bond yield spreads in emerging market countries. However, these studies fail to consider the potential effects of countercyclical capital flows, especially remittance inflows on bond spreads. In this paper, we contribute to filling this gap by examining the impact of remittances on sovereign bond spreads. Using a panel data of 38 emerging market countries over the period 1993-2012, we contribute to the existing literature on spread determinants in several areas.

First, we find that remittance inflows significantly reduce bond spreads in emerging market countries. The magnitude of the estimated effect is economically meaningful: a 1 percent increase of remittances-to-GDP inflows results in spread saving of approximately 3 basis points. We provide several possible interpretations of this finding. Given the fact that remittances increase the fiscal space in the recipient country and are countercyclical in nature, we believe that remittances reduce the government's marginal cost of raising revenues and act as an insurance mechanism against negative shocks which affect bond markets. We also believe that remittance securitization and diaspora bonds play some part in explaining this beneficial effect. Our findings are robust to a wide set of alternative specifications, including the use of additional control variables, alternative definitions of sovereign risk premiums and remittances, changes in the sample definition and the time horizon, and the use of alternative instrumentation techniques. Second, we explore the heterogeneity of the estimated effect of remittances. We find that remittances reduce bond spreads in countries with a poorly developed financial system, a high degree of trade openness or a low degree of fiscal space. We also find that the beneficial effect of remittances disappears for remittance-dependent countries. These findings confirm that there is a fiscal space channel through which remittances can reduce government borrowing costs. However, we do not explore all possible channels mentioned in the first section of this paper. In particular, the lack of appropriate data does not allow us to test for a securitization channel and diaspora bonds channel.

Our results have policy implications. The evidence that remittances reduce bond spreads suggests that emerging market countries should increase their efforts to improve the measurement of remittance inflows and reduce transfer costs. We believe that policy-makers would properly gauge the effect of remittances on bond markets by improving remittance measurement and reducing transfer costs. Admitting that we did not give insights on all the channels through which remittances may affect bond spreads, we also believe that policies aimed at developing the securitization of remittances and diaspora bonds may also increase 
the beneficial effect of remittances. Lastly, the biggest challenge for remittance-dependent countries is to put in place concrete policy measures to leverage remittances for international capital market access.

\section{References}


- Acosta, P.A., Larley, E.K., Mandelman, F.S. 2009. Remittances and the Dutch disease, Journal of International Economics 79, 102-116.

- Aggarwal, R., Demirgüç-Kunt, A., Peria, M.S.M. 2011. Do remittances promote financial development? Journal of Development Economics 96, 255-264.

- Aizenman, J., Hutchison, M., Jinjarak, Y. 2013. What is the risk of European sovereign debt defaults? Fiscal space, CDS spreads and market pricing of risk. Journal of International Money and Finance 34, 37-59.

- Arellano, C. 2008. Default risk and income fluctuations in emerging economies, American Economic Review 98, 690-712.

- Arezki, R., Brückner, M. 2011. Resource Windfalls and Emerging Market Sovereign Bond Spreads: The Role of Political Institutions, World Bank Economic Review, 26, 1, 78-99.

- Arora, V., Cerisola, M. 2001. How Does U.S. Monetary Policy Influence Sovereign Spreads in Emerging Markets? IMF Staff Papers 48, 474-498.

- Arslanalp, S., Poghosyan, T. 2014. Foreign Investor Flows and Sovereign Bond Yields in Advanced Economies, IMF wp, 14/27.

- Baldacci, E., Gupta, S., Mati, A. 2011. Political and fiscal risk determinants of sovereign spreads in emerging markets, Review of Development Economics 15, 251-263.

- Baldacci, E., Kumar, M.S. 2010. Fiscal Deficits, Public Debt, and Sovereign Bond Yields, IMF wp 10/184.

- Bellas, D., Papaioannou, M., Petrova, I. 2010. Determinants of emerging market sovereign bond spreads: fundamentals vs financial stress, IMF wp 10/281.

- Bourdet, Y., Falck, H. 2006. Emigrants' remittances and Dutch disease in Cape Verde, International Economic Journal 20, 267-284.

- Chami, R., Abdih, Y., Gapen, M., Mati, A. 2009. Fiscal Sustainability in Remittance-Dependent Economies, IMF wp 09/190.

- Chami, R., Barajas, A., Cosimano, T., Fullenkamp, C., Gapen, M., Montiel, P. 2008. Macroeconomic Consequences of Remittances, IMF Occasional Paper \#259.

- Clemens, M.A., McKenzie, D. 2014. Why don’t remittances appear to affect growth? World Bank Policy Research wp \#6856.

- Combes, J.L., Ebeke, C. 2011. Remittances and household consumption instability in developing countries, World Development 39, 1076-1089.

- Comelli, F. 2012. Emerging market sovereign bond spreads: Estimation and back-testing, Emerging Markets Review 13, 598-625.

- Costantini, M., Fragetta, M., Melisa, G. 2014. Determinants of sovereign bond yield spreads in the EMU: An optimal currency area perspective, European Economic Review 70, 337-349.

- Edwards, S. 1984. LDC Foreign Borrowing and Default Risk: An Empirical Investigation, American Economic Review 74, 726-734.

- Eichler, S. 2014. The political determinants of sovereign bond yield spreads, Journal of International Money and Finance 46, 82-103.

- Elmendorf, D.W., Mankiw, N.G. 1999. Government debt, Handbook of Macroeconomics 1, 3, 1615-1669.

- Frankel, J. 2011. Are Bilateral Remittances Countercyclical? Open Economies Review 22, 1, 1-16. 
- Frankel, J.A, Vegh, C.A., Vuletin, G. 2013. On the graduation from fiscal procyclicality, Journal of Development Economics 100, 32-47.

- Freund, C., Spatafora, N. 2008. Remittances, transaction costs, and informality. Journal of Development Economics 86, 356-366.

- Galvin, M., Perotti, R. 1997. Fiscal Policy in Latin America, NBER Macroeconomics Annual 12, 11-72.

- Giuliano, P., Ruiz-Arranz, M. 2009. Remittances, financial development, and growth. Journal of Development Economics 90, 144-152.

- Hansen, B., 2000. Sample splitting and threshold estimation, Econometrica 68, 575-603.

- Hatchondo, J., Martinez, L., Roch, F. 2012. Fiscal rules and the sovereign default premium, IMF wp 12/30.

- Hilscher, J., Nosbusch, Y. 2010. Determinants of sovereign risk: Macroeconomic fundamentals and the pricing of sovereign debt, Review of Finance 14, 235-262.

- International Monetary Fund. 2005. World Economic Outlook (April).

- Jaramillo, L., Tejada, C. M. 2011. Sovereign Credit Ratings and Spreads in Emerging Markets: Does Investment Grade Matter? IMF wp 11/44.

- Mandelman, F.S. 2013. Monetary and exchange rate policy under remittances fluctuations, Journal of Development Economics, 102, 128-147.

- Ostry, J.D., Ghosh, A.R., Kim, J.I., Qureshi, M.S. 2010. Fiscal space, IMF Staff Position Note 10/11, 1-24.

- Ratha, D. 2007. Leveraging Remittances for Development, MPI Policy Brief, 1-15.

- Shapiro, A.F., Mandelman, F.S. 2016. Remittances, entrepreneurship, and employment dynamics over the business cycle, Journal of International Economics, 103, 184-199.

- Shimeles, A. 2010. Diaspora Bonds and Securitization of Remittances for Africa's Development, AfDB Africa Economic Brief 1, 1-7.

- Staiger, D., Stock, J.H. 1997. Instrumental Variables Regression with Weak Instruments, Econometrica 65 , 557-586.

- Sy, A.N. 2002. Emerging market bond spreads and sovereign credit ratings: reconciling market views with economic fundamentals, Emerging Markets Review 3, 380-408.

- Zhu, H. 2006. An Empirical comparison of Credit Spreads between the Bond Market and the Credit Default Swap Market, Journal of Financial Services Research 29, 211-235. 